\title{
Food and nutrient intakes of a population sample of 3-year-old children in the South West of England in 1996
}

\author{
Pauline Emmett*, Imogen Rogers, Carol Symes and the ALSPAC Study Team \\ Unit of Paediatric and Perinatal Epidemiology, University of Bristol, 24 Tyndall Avenue, Bristol BS8 1TQ, UK
}

Submitted 5 March 2001: Accepted 15 June 2001

\begin{abstract}
Objective: To investigate food and nutrient intakes in 3-year-old children.

Subjects: Eight hundred and sixty-three children resident in South West England (69\% of those invited at this age), a randomly selected sub-sample of the Avon Longitudinal Study of Pregnancy and Childhood (ALSPAC).

Methods: Diet was assessed using a 3-day descriptive food record. Food and nutrient intakes were compared with intakes at 18 months in the same children, with intakes in the British National Diet and Nutrition Survey (NDNS) of pre-school children, and with dietary reference values (DRVs).

Results: Intakes of energy and most nutrients had increased between 18 and 43 months. The macronutrient content of the diet had also changed, the percentage of energy from starch rose from 21 to $23 \%$ and from non-milk extrinsic (NME) sugar from 12 to $16 \%$, while the polyunsaturated to saturated fat ratio increased from 0.26 to 0.33 . When compared with the NDNS, intakes of energy and all nutrients were higher with the exception of NME sugar. Energy intakes were below the estimated average requirements. Mean intakes of iron and vitamin D were below the Reference Nutrient Intake. Fewer children were eating beef at 43 months than at 18 months. Total daily meat consumption was lower than in the NDNS. The proportion of children consuming any vegetables dropped between 18 and 43 months, although fruit eating remained constant.

Conclusions: The diets of 3-year-olds in this study were adequate in most nutrients. Our results suggest that energy requirements of pre-school children in the 1990s are less than the DRV. Nutrient and food intakes changed between 18 and 43 months. Children were eating less meat than their counterparts in the NDNS.
\end{abstract}

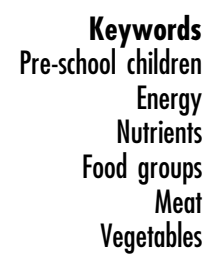

Many chronic diseases that occur in older adults such as coronary heart disease and some cancers have been related to the intake of a number of dietary factors, which may be protective or detrimental ${ }^{1-7}$. Britain has higher levels of many of these diseases than other countries in the Western world ${ }^{8}$. This could be related to the type of diet habitually eaten in Britain. The precursors of some of these diseases start in childhood ${ }^{9,10}$ and this is also the time when dietary habits start to be formed ${ }^{11}$.

Information about the dietary habits of a cohort of around 1000 children was collected at age 18 months ${ }^{12}$ in 1994 and at 43 months in 1996; the present analysis looks at the nutrient and food group intakes of these children. These are compared with data in the published report from the British National Diet and Nutrition Survey (NDNS), which assessed the diets of 250 boys and 243 girls aged between $31 / 2$ and $41 / 2$ years $^{13}$. The fieldwork for the NDNS was carried out over a 12-month period in $1992 / 3$. The nutrient and energy intakes are also compared with dietary reference values (DRVs) for the United Kingdom ${ }^{14}$, to assess adequacy of the diet. Weights of various foods eaten are compared between 18 and 43 months and with the NDNS.

\section{Methods}

The data for this study were obtained from the Avon Longitudinal Study of Pregnancy and Childhood (ALSPAC), a prospective cohort study designed to identify features of the environment that influence the health and development of children ${ }^{15,16}$. Pregnant women with an expected date of delivery between 1 April 1991 and 31 December 1992, resident in the three Bristol-based National Health Service Trust areas in South West England, were eligible for the study. Around 85\% of eligible mothers enrolled (14000 pregnancies). When compared with the 1991 British National Census data of mothers with infants under one year resident in the area, 
the ALSPAC population demonstrated a slight shortfall in those living in rented accommodation, those without a car, single-parent families, unmarried cohabiting couples and ethnic minorities. In-depth information was obtained from a randomly selected sub-sample of the children born between June and December 1992 (equivalent to 10\% of the whole cohort), known as 'Children in Focus' (CIF). These children were invited to several clinics during their early years, where a variety of physical and developmental measures were taken. Ethical approval for the study was obtained from the three Health Trusts covering the study area and from the ALSPAC ethical committee.

Between January and July 1996, each child (aged around $31 / 2$ years ( 43 months)) and their main carer were invited to attend a clinic. As part of the assessment, carers were asked to record in a structured diary all of the foods and drinks that their child consumed over three individual days prior to the clinic: one weekend day and two weekdays. They were asked to bring their completed diaries to the clinic, where they were interviewed to clarify any anomalies in the diary. Foods and drinks were recorded in household measures. For drinks, details of the amount of concentrate used in diluted drinks, use of additives such as sugar, total volume offered and leftover amount were recorded. For foods, a full description of the food and the amount offered was requested with a separate section for description of leftovers. Each diary also contained a section to record if anyone else had provided any of the main meals that day, if so who this person was, if all the food eaten that day had been recorded and whether the day had been typical for the child. There was a space for comment on the reason for it not being typical. A short questionnaire was also included, which asked about the use of vitamin supplements, types of spread normally used on bread, and other details of foods commonly eaten, to aid coding.

The completed dietary diaries were coded (by CS) using the computer program DIDO (Diet In, Data Out) ${ }^{17}$, originally developed by a team from the Human Nutrition Research Unit in Cambridge. The program generates a food code and an associated weight for each item of food and drink recorded. The coding of all diaries was checked against the original records and errors were corrected.

The databank used for the nutrient analysis included the fifth edition of McCance and Widdowson's food tables $^{18}$, and the supplements to the tables ${ }^{19-27}$. Wherever possible the most up-to-date nutrient data were used; e.g. meats were coded using the meat, poultry and game supplement ${ }^{27}$ rather than the fifth edition of the food tables. This was done on the assumption that the nutrient composition of food may change over a period of time and methods of analysis may improve. The portion sizes used were based on those given in the Ministry of Agriculture, Fisheries and Foods' (MAFF) Food Portion Sizes booklet (second edition) ${ }^{28}$ and from given weights of manufactured products. Where no other information was available adult portion sizes were scaled down to child-size portions, i.e. for main courses to 0.5 and for puddings and cereals to 0.6 (these were estimated portion sizes and no difference was made between boys and girls). A number of other foods and portion sizes were added to make the database more suitable for coding the diets of young children, such as confectionery items and soft drinks. Where data for specific nutrients in some foods were missing from the food tables, estimates of the nutrient content were made and added to the tables; this reduces the possibility of underestimating some nutrient intakes ${ }^{29}$.

An in-house nutrient analysis program was used to generate the nutrient analysis for each food that the child ate. The average daily nutrient intakes and amount consumed of various groups of foods were calculated. Diaries that produced very high or very low estimates of intake for some nutrients (energy, protein, fat, carbohydrate, calcium, iron, folate and vitamin C) were rechecked (by PE); this amounted to $10 \%$ of the diaries. Minor adjustments were made to half of these and more substantial adjustments to $3 \%$.

Nutrient intakes from dietary supplements were not included in this analysis. However, around one-quarter of the children were recorded in the questionnaire as receiving vitamin supplements (18.2\% daily, 4.8\% 4-6 times a week, 3.0\% 2-3 times a week, $0.8 \%$ once a week and $1.9 \%$ less than once a week).

Non-milk extrinsic sugar (NME sugar) was calculated from total sugars by deducting all the sugar provided by fresh fruit, vegetables and milk and part of that provided by tinned fruit, baked beans, yoghurt and fromage frais.

\section{Statistical methods}

Differences between nutrient intakes according to factors affecting recording of the diet

The mean nutrient intakes from each day of the week recorded were compared by one-way analysis of variance or Kruskal-Wallis tests, to determine whether it was necessary to weight the mean intakes of each child according to the particular days of the week recorded. Overall mean intakes were then labelled according to whether a Sunday had been recorded or not. The intakes with or without a Sunday included were compared using Student $t$-tests or Mann-Whitney $U$-tests, keeping the sexes separate.

Recorded days that the carer had indicated were not typical of the child's normal eating pattern - either because the child was unwell or for some other reason were compared with typical days, using one-way analysis of variance or Kruskal-Wallis tests. Recorded days where the carer had indicated that another person had given the child some of their meals were compared with days where all of the meals had been provided by the main carer, using Student $t$-tests or Mann-Whitney $U$-tests. 
Energy requirements and under- or overreporting of energy intake

Underreporting of energy intake is a major problem in dietary surveys of adults ${ }^{30,31}$ and older children ${ }^{32}$. To investigate the extent of under- or overreporting in this survey, observed or reported energy intakes (OEI) calculated from the dietary diaries were compared with predicted energy intakes (PEI). If PEI exceeded OEI by more than $1290 \mathrm{~kJ}$ the child was considered a possible underreporter, whereas if the reverse was true the child was considered a possible overreporter. This value (1290 kJ) represents $22.2 \%$ of the overall mean value as suggested by Davies et al. in an analysis of energy intakes related to energy expenditure in the NDNS ${ }^{33}$. Alternatively, predicted energy expenditure (PEE) was calculated and children with an OEI below this were considered to be underreporters. No estimates for over-recording were produced by this method. Four different methods were used to calculate either PEI or PEE so that OEI could be compared with four different predicted levels.

- Method 1 - PEI using the Estimated Average Requirement (EAR) for energy per kg body weight given in the 1991 Dietary Reference Values for the United Kingdom $^{14}$. Taking the mid-point between the figures for 3- and 4-year-olds (400 and $375 \mathrm{~kJ} \mathrm{~kg}^{-1}$ for boys and girls, respectively) and then multiplying by the weight of the child at 43 months.

- Method 2 - PEI using figures derived from doubly labelled water measurements of energy expenditure in young children ${ }^{34}$ (334 and $314 \mathrm{~kJ} \mathrm{~kg}^{-1}$ in boys and girls, respectively) and multiplying by weight as before.

- Methods 3 and 4 - PEE using the equations for calculating basal metabolic rate (BMR) from body weight given in the $1985 \mathrm{FAO} / \mathrm{WHO} / \mathrm{UNU}$ report on protein and energy requirements ${ }^{35}$ with an increment added for physical activity. Two levels of increment were used: 135\% of BMR as suggested by the World Health Organization (WHO) ${ }^{35}$ and $120 \%$ of BMR, because energy expenditure on physical activity in young children has been shown to be at this level in a study in the $\mathrm{USA}^{36}$.

\section{Differences according to the sex of the child}

The differences between nutrient intakes and energy density in boys and girls were assessed using the Student $t$-test or Mann-Whitney $U$-test.

\section{Results}

\section{Response rate}

A total of 1249 children were invited to attend for assessment at 43 months of age, and 1065 attended. Dietary diaries were completed by 863 (69.1\% of those invited); of these, 724 completed 3-day diaries, 80 completed 2-day diaries and 59 one day only. The days recorded were not necessarily consecutive. Boys who did not have their diet recorded were slightly taller and heavier than those who did (mean (standard deviation, SD) height: 100.5 (3.9) vs. 99.6 (3.6) cm, $P=0.025$, respectively; weight: 16.8 (1.9) vs. 16.4 (1.8) kg, $P<0.05$, respectively). There was no difference between the girls who did or did not supply dietary records for these variables (mean (SD) height: 98.6 (3.6) $\mathrm{cm}$ and weight: 16.0 (2.0) $\mathrm{kg}$ for girls with diaries). The mothers of children who did not attend the clinic differed in educational qualifications from those who did (e.g. $27.7 \%$ vs. $11.8 \%$ in the lowest educational group, chisquared $P<0.001$, compared with $20.8 \%$ in ALSPAC as a whole). However, there was no significant difference in educational qualifications between those attending who did or did not complete dietary diaries for their children.

\section{Differences between nutrient intakes according to days of the week recorded}

The day of the week most frequently recorded was Sunday $(n=446)$ and the least recorded day was Thursday $(n=262)$. When mean or median estimated nutrient intakes on the different days of the week were compared, all days were very similar except for Sunday. Sundays were not recorded in all of the diaries so we compared the estimated intakes for each child where a Sunday had been recorded with those where it had not. In both sexes carotene intakes and hence retinol equivalents were higher if a Sunday had been recorded. In boys calcium intakes were lower and in girls the energy contribution from protein was higher if a Sunday had been recorded. As these differences were small and affected so few nutrients, it was not considered necessary to adjust for days of the week recorded.

\section{The effect on nutrient intake of illness and otber atypical days}

Carers had been asked to choose to record days that were likely to be typical of their child's normal eating pattern and therefore the number of atypical days recorded was not large. On $2.3 \%$ of recorded days the child was said to be unwell, $9.8 \%$ of days were said to be atypical for other reasons (e.g. birthday party attended, visitors came). Intakes of all nutrients except carotene and vitamin $\mathrm{C}$ were significantly lower if the child was unwell on the recording day (with the difference ranging from 15 to $29 \%$ lower). If the day was atypical for other reasons fewer nutrient intakes were affected: intakes of protein, potassium, iodine, zinc, riboflavin, thiamine and vitamin $\mathrm{B}_{6}$ were significantly lower (by around 5 to 10\%). As comparatively few diaries were affected, no adjustment was made for this. 
Table 1 Assessing the estimated degree of over- or underreporting of energy intake from dietary diaries collected from 43-month-old children, by four different methods described fully in the text

\begin{tabular}{llccc}
\hline & & $\begin{array}{c}\text { Predicted minus } \\
\text { observed energy (kJ) }\end{array}$ & $\begin{array}{c}\text { \% of children } \\
\text { 'underreporting' }\end{array}$ & $\begin{array}{c}\text { \% of children } \\
\text { 'overreporting' }\end{array}$ \\
\hline Method 1 & Boys & 748 & 32 & 4 \\
Method 2 & Girls & 527 & 22 & 5 \\
& Boys & -333 & 8 & 21 \\
Method 3 & Girls & -450 & 5 & 20 \\
& Boys & NA & 19 & NA \\
Method 4 & Girls & NA & 25 & NA \\
& Boys & NA & 8 & NA \\
\hline
\end{tabular}

$\mathrm{NA}=$ not applicable.

\section{The effect on nutrient intake of someone otber than the main carer looking after the child for some meals}

The total number of days recorded was 2391. Someone other than the main carer had given the child at least one main meal on 702 days (29.4\%). More than one meal was involved on $26 \%$ of these days. Half of the meals affected were at midday. The person most likely to be involved was the partner of the carer (33.5\%), followed by a relative $(21.1 \%)$, at nursery $(17.2 \%)$, at play school (12.3\%), a minder or nanny (11.2\%) or a friend $(3.8 \%)$. There were very few differences in nutrient intake between days when the main carer was the sole provider of meals and those where someone else was involved. Mean protein, total sugar and calcium intakes were all slightly higher when someone else had provided a meal.

\section{Energy requirements and under-or overreporting of intake}

Table 1 shows the extent of under- or overreporting estimated by the four different methods of calculating PEI or PEE. Predicting energy intake from EAR resulted in a large positive difference between PEI and OEI and a large proportion of children being labelled as underreporters (Method 1). There was a smaller negative difference and far fewer children labelled as underreporters if doubly labelled water measurements of energy expenditure were used to obtain PEI (Method 2). Similarly, the lower level of PEE using 120\% of BMR as the cut-off (Method 4) identified many fewer underreporters than that using 135\% (Method 3), and found similar levels of underreporting to Method 2. The data presented in the rest of this paper have not been adjusted for over- or underreporting.

\section{Differences between nutrient intakes and nutrient density according to the sex of the child}

The mean estimated dietary intakes of the macronutrients and selected micronutrients in CIF at 43 months are shown in Table 2 for boys and Table 3 for girls. The mean nutrient intakes in the CIF at 18 months and the percentage change from 18 to 43 months are also shown, along with the mean intakes (from food sources only) for the children aged between $31 / 2$ and $41 / 2$ years in the NDNS.

Table 2 The mean (SD) nutrient intakes estimated from dietary records kept at 18 and 43 months of age in boys in the Children in Focus population sample, with data (from food sources only) from the National Diet and Nutrition Survey (NDNS) of 3 1/2- to 4 1/2-year-old boys for comparison

\begin{tabular}{|c|c|c|c|c|}
\hline Nutrient & $\begin{array}{l}\text { Mean (SD) } \\
\text { at } 18 \text { months } \\
\quad(n=563)\end{array}$ & $\begin{array}{l}\text { Mean }(\mathrm{SD}) \\
\text { at } 43 \text { months } \\
\quad(n=488)\end{array}$ & $\begin{array}{l}\text { Percentage change } \\
\text { from } 18 \text { to } \\
43 \text { months }\end{array}$ & $\begin{array}{c}\text { Mean }(S D) \text { at } 31 / 2 \text { to } \\
41 / 2 \text { years from NDNS } \\
(n=250)\end{array}$ \\
\hline$\overline{\text { Energy }(\mathrm{kJ})^{*}}$ & $4765(938)$ & 5809 (1099) & +22.0 & $5356(1119)$ \\
\hline Energy $(\mathrm{kJ}) / \mathrm{kg}$ body weight & 406 & $357(72)$ & & 323 \\
\hline Protein $(g)$ & $42.7(10.4)$ & $48.0(11.9)$ & +12.4 & $39.4(10.4)$ \\
\hline Fat $(\mathrm{g})$ & $48.3(12.1)$ & 56.8 (14.3) & +17.6 & $50.1(13.4)$ \\
\hline Saturated fat $(\mathrm{g})$ & $23.1(6.6)$ & $25.3(7.7)$ & +9.5 & $21.9(6.5)$ \\
\hline Polyunsaturated fat $(\mathrm{g})^{*}$ & $5.6(2.3)$ & 7.79 (2.9) & +39.2 & $6.8(2.5)$ \\
\hline Monounsaturated fat $(\mathrm{g})$ & $15.5(4.2)$ & $18.6(4.8)$ & +20.0 & $15.7(4.4)$ \\
\hline Carbohydrate $(\mathrm{g})$ & $141(31)$ & $181(36)$ & +28.4 & $177(41)$ \\
\hline Total sugar $(\mathrm{g})$ & $78.1(21.3)$ & $92.4(26.3)$ & +18.4 & 98 (33.2) \\
\hline NME sugar (g) & $37.0(18.5)$ & $58.8(22.5)$ & +58.9 & $69(30.0)$ \\
\hline Starch $(g)$ & $62.1(19.2)$ & $86.9(22.3)$ & +39.9 & $79(22.1)$ \\
\hline Vitamin C $(\mathrm{mg})^{\star}$ & $54.5(49.6)$ & 53.1 (41.3) & -2.6 & $50.8(41.1)$ \\
\hline Iron $(\mathrm{mg})^{*}$ & $5.48(1.95)$ & $6.41(1.72)$ & +17.0 & $5.6(1.74)$ \\
\hline Calcium $(\mathrm{mg})^{*}$ & $829(259)$ & $796(287)$ & -4.0 & $625(226)$ \\
\hline Zinc $(m g)^{*}$ & $5.10(1.31)$ & $5.31(1.52)$ & +4.1 & $4.7(1.42)$ \\
\hline lodine $(\mu g)^{\star}$ & $184(93)$ & $157.2(83.4)$ & -14.7 & $121(56.9)$ \\
\hline
\end{tabular}

* Non-parametric statistics were used for the comparison between boys and girls. 
Table 3 The mean (SD) nutrient intakes estimated from dietary records kept at 18 and 43 months of age in girls in the Children in Focus population sample, with data (from food sources only) from the National Diet and Nutrition Survey (NDNS) of 3 1/2- to 4 1/2-year-old girls for comparison

\begin{tabular}{|c|c|c|c|c|}
\hline Nutrient & $\begin{array}{l}\text { Mean (SD) } \\
\text { at } 18 \text { months } \\
\quad(n=463)\end{array}$ & $\begin{array}{l}\text { Mean (SD) } \\
\text { at } 43 \text { months } \\
(n=375)\end{array}$ & $\begin{array}{l}\text { Percentage change } \\
\text { from } 18 \text { to } \\
43 \text { months }\end{array}$ & $\begin{array}{c}\text { Mean (SD) at } 31 / 2 \text { to } \\
41 / 2 \text { years from NDNS } \\
(n=243)\end{array}$ \\
\hline Energy $(\mathrm{kJ})$ & $4441(908)$ & $5492(1034)$ & +23.7 & $4978(1023)$ \\
\hline Energy $(\mathrm{kJ}) / \mathrm{kg}$ body weight & 401 & $345(68)$ & & 304 \\
\hline Protein $(g)$ & $40.1(9.8)$ & $45.1(11.4)$ & +12.5 & $37.7(10.5)$ \\
\hline Fat $(g)$ & $45.1(11.7)$ & $54.3(13.0)$ & +20.4 & $47.2(13.6)$ \\
\hline Saturated fat $(\mathrm{g})$ & $21.7(6.5)$ & $24.2(7.0)$ & +11.5 & $20.6(6.6)$ \\
\hline Polyunsaturated fat (g) & $5.06(2.1)$ & $7.51(2.9)$ & +48.4 & $6.4(2.5)$ \\
\hline Monounsaturated fat $(\mathrm{g})$ & $14.5(3.9)$ & $17.8(4.5)$ & +22.8 & $14.8(4.5)$ \\
\hline Carbohydrate (g) & $131(29)$ & $170(34)$ & +29.8 & $162(33)$ \\
\hline Total sugar $(\mathrm{g})$ & $72.3(19.4)$ & $88.6(23.4)$ & +22.5 & $88(26.5)$ \\
\hline NME sugar & $33.8(17.4)$ & $56.8(21.2)$ & +68.0 & $60(25.0)$ \\
\hline Starch $(g)$ & $57.9(18.7)$ & $80.0(23.9)$ & +38.2 & $74(20.3)$ \\
\hline Vitamin C (mg) & $48.0(43.0)$ & $56.0(37.5)$ & +16.7 & $45.9(31.2)$ \\
\hline Iron (mg) & $5.20(1.70)$ & $6.07(1.92)$ & +16.7 & $5.6(1.56)$ \\
\hline Calcium (mg) & $777(250)$ & $732(278)$ & -5.8 & $595(212)$ \\
\hline Zinc (mg) & $4.8(1.2)$ & $4.9(1.4)$ & +2.7 & $4.4(1.4)$ \\
\hline lodine $(\mu \mathrm{g})$ & $173(89)$ & $145(80)$ & -16.2 & $113(56)$ \\
\hline
\end{tabular}

Intakes of energy and all macronutrients, except polyunsaturated fat, were significantly higher in boys than in girls at 43 months. Boys also had higher recorded intakes of fibre and most minerals. The intakes of several of the vitamins, however, were not significantly different between boys and girls, including folate and vitamin D (data not shown).

Table 4 shows the percentage of energy provided by each of the macronutrients for both sexes together in CIF at 43 and 18 months and in the NDNS. The polyunsaturated fat to saturated fat ratio $(\mathrm{P} / \mathrm{S})$ and the fat to carbohydrate ratio $(\mathrm{F} / \mathrm{C})$ are also shown. There was no difference between the boys and girls at 43 months once energy intakes had been controlled for in this way (data not shown), except in the contribution of starch to energy: $23.8 \%$ in boys and $23.0 \%$ in girls $(P=0.024)$. When vitamin and mineral intakes per unit of energy were calculated and compared between boys and girls, there were very few significant differences. Boys had

Table 4 The percentage contribution to energy intake from macronutrients and the ratios of polyunsaturated fat to saturated fat $(\mathrm{P} / \mathrm{S})$ and fat to carbohydrate $(\mathrm{F} / \mathrm{C})$ in the diet of children at 18 and 43 months and in the National Diet and Nutrition Survey (NDNS) at $31 / 2-41 / 2$ years

\begin{tabular}{lccc}
\hline Percentage of energy from & 18 months & 43 months & NDNS \\
\hline Protein & 14.4 & 13.9 & 12.6 \\
Carbohydrate & 46.7 & 49.2 & 52.0 \\
$\quad$ NME sugar & 12.3 & 16.4 & 19.8 \\
Starch & 20.8 & 23.4 & 23.3 \\
Fat & 38.3 & 37.1 & 35.4 \\
$\quad$ Saturated & 18.0 & 16.5 & 15.6 \\
$\quad$ Monounsaturated & 12.0 & 12.1 & 11.2 \\
Polyunsaturated & 4.3 & 5.2 & 4.9 \\
P/S* $^{*}$ & 0.26 & 0.33 & 0.31 \\
F/C $^{*}$ & 0.35 & 0.32 & 0.29 \\
\hline
\end{tabular}

${ }^{*}$ Non-parametric statistics were used for the comparison between boys and girls. significantly higher copper and magnesium intakes for each unit of energy and girls had higher intakes of dietary cholesterol, vitamin $\mathrm{C}$ and vitamin $\mathrm{E}$ (data not shown).

\section{Comparison between nutrient intakes from dietary records obtained at 18 and 43 months and with the NDNS (Tables 2-4)}

In the two years between the dietary recordings taken at 18 and 43 months, the average intake of most nutrients had increased. The exceptions to this were iodine, calcium and vitamin $C$. The overall increase in energy intake was $22.0 \%$ in boys and $23.7 \%$ in girls. However, some of the energy-producing nutrients showed larger proportional increases and others smaller. Fat intake was noteworthy, with a small increase in saturated fatty acids but a large increase in polyunsaturated fatty acids, resulting in a large change in the $\mathrm{P} / \mathrm{S}$ ratio between 18 and 43 months. Starch also showed a large proportional increase. The increase in total sugar was in line with the increase in energy intakes, but the increase in NME sugar intake was much greater.

Compared with the NDNS, the estimated absolute intakes in this study were higher for energy and all of the energy-providing nutrients apart from total and NME sugar. However, a smaller percentage of energy came from carbohydrate and more from protein and fat in CIF compared with the NDNS. All three types of fat contributed to the greater percentage of fat, but the difference in carbohydrate contribution to energy was entirely because of a lower proportion of NME sugar in CIF.

\section{Comparison with dietary reference values}

Table 5 shows the mean and median nutrient intakes in CIF at 43 months in comparison with the dietary reference values for children aged $1-3$ years $^{14}$. 
Table 5 Mean (SD) and median nutrient intakes at 43 months in comparison with the dietary reference values for children aged 1-3 years

\begin{tabular}{|c|c|c|c|}
\hline Nutrient & Mean (SD) & Median & $\mathrm{RNI}^{*}$ \\
\hline \multicolumn{4}{|l|}{ Energy (kJ) } \\
\hline Boys & 5809 (1099) & 5726 & 6480 (EAR†) \\
\hline Girls & $5491(1034)$ & 5481 & 5930 (EAR +$)$ \\
\hline Protein $(\mathrm{g})$ & $46.7(11.8)$ & 45.6 & 14.5 \\
\hline Calcium (mg) & 768 (285) & 732 & 350 \\
\hline Iron (mg) & $6.3(1.8)$ & 6.1 & $\begin{array}{l}6.9\left(\mathrm{RNI}^{\star}\right) \\
5.3(\mathrm{EAR}+)\end{array}$ \\
\hline Zinc (mg) & $5.14(1.49)$ & 4.95 & 5.0 \\
\hline lodine $(\mu \mathrm{g})$ & $152(82)$ & 133 & 70 \\
\hline Potassium (mg) & 1877 (492) & 1828 & 800 \\
\hline Magnesium (mg) & $168(43)$ & 163 & 85 \\
\hline Sodium (mg) & $1823(469)$ & 1789 & 500 \\
\hline Selenium $(\mu \mathrm{g})$ & $42.3(14.0)$ & 40.9 & 15 \\
\hline Retinol equivalents $(\mu \mathrm{g})$ & $535(362)$ & 479 & 400 \\
\hline Niacin equivalents (mg) & $20.6(5.2)$ & 20.2 & 6.6 \\
\hline Riboflavin (mg) & $1.47(0.47)$ & 1.42 & 0.6 \\
\hline Thiamine (mg) & $0.98(0.37)$ & 0.94 & 0.4 \\
\hline Vitamin $B_{6}(\mathrm{mg})$ & $1.32(0.37)$ & 1.28 & 0.7 \\
\hline Folate $(\mu \mathrm{g})$ & $152(45)$ & 147 & 70 \\
\hline Vitamin C (mg) & $54.4(39.7)$ & 42.2 & 30 \\
\hline Vitamin D $(\mu \mathrm{g})$ & $1.79(1.36)$ & 1.61 & 7 \\
\hline
\end{tabular}

* Reference Nutrient Intake.

$\dagger$ Estimated Average Requirement.

Energy intakes were low compared with reference values. The mean intakes of most vitamins and minerals were well above the reference nutrient intake (RNI); however, mean iron intakes were slightly below and mean zinc intakes around the RNI, whereas vitamin D intakes were very much lower. Nutrients from dietary supplements were not included in this analysis as only a minority (18\%) were having them regularly.

\section{Types of foods eaten}

Table 6 shows the mean weights of each food group eaten averaged over the whole sample (consumers and non-consumers) and the percentage of children consuming the item at 43 and 18 months, with comparable figures from the NDNS where available. The average amount consumed for many foods had increased slightly between 18 and 43 months, as might be expected from the increased size and energy requirements of the children. However, the consumption of some foods had fallen markedly. These were foods associated with a postweaning diet, such as baby foods and drinks and whole milk. The consumption of foods popular with young children increased considerably; these included savoury snacks, potato products, bread and breakfast cereals. The weights of foods such as other potatoes, meat, fruit and vegetables had changed much less. Notably, the proportion of children consuming beef or vegetables had decreased between 18 and 43 months. Compared with the weighed intakes in the NDNS, the estimated weights in this study were often higher: for example, bread, milk, fruit, breakfast cereals and potatoes. However, the estimated total amount of meat eaten in this study was lower than in the NDNS. This was due to lower intakes of burgers, sausages and pies, although intakes of chicken dishes and lamb and lamb dishes were higher. In total, $15.4 \%$ of children ate no red meat during the 3-day recording period, and $6.1 \%$ ate no meat of any type.

Taking all vegetables together, except potatoes and baked beans, $17.0 \%$ ate none during the recording period and a similar proportion (17.4\%) ate no fruit. A quarter of children ate less than $50 \mathrm{~g}$ per day of fruit and vegetables added together and some ate none of either (4.6\% of all children).

\section{Discussion}

The mean dietary intakes of energy and most nutrients were higher in boys than girls. Boys consumed slightly larger amounts of most food groups than girls, although the same basic portion sizes were used. However, the quality of the diet - as judged by the percentage of energy contributed by each of the macronutrients and the intake of micronutrients per unit of energy - was very similar. Similar differences between the sexes had been found at 18 months in CIF and at each age in NDNS. This difference was due to the fact that the boys were slightly larger than the girls at 43 months, and also had a slightly greater mean intake of energy per $\mathrm{kg}$ body weight. Perhaps, at this age, boys are more active than girls.

Some substantial changes in nutrient intake and types of foods eaten were seen between 18 and 43 months. There was a large proportional increase in starch intake coupled with a fall in iodine and calcium intakes. This was probably the result of the change from a postweaning diet, including a high proportion of milk, to a child's diet with less milk and more bread and other starchy foods. Milk is one of the main sources of calcium and iodine in the British diet. In fact, the overall level of milk consumption had fallen by $119 \mathrm{~g}$ a day while the consumption of bread, potato products, savoury snacks, breakfast cereals and biscuits had all increased. The decrease in milk intake may also be partly responsible for the change in $\mathrm{P} / \mathrm{S}$ ratio since it contains a high proportion of saturated fat. Increase in the use of polyunsaturated spreads and fewer children eating beef added to this. This increase in $\mathrm{P} / \mathrm{S}$ ratio may mean that the diet was slightly less atherogenic, since, in adults at least, increasing $\mathrm{P} / \mathrm{S}$ ratio has been associated with decreasing blood concentrations of total cholesterol ${ }^{37-39}$. There was a large increase in NME sugar intake between 18 and 43 months, due mainly to an increased number of consumers of sweet foods, particularly sugar confectionery. There was also an unexpected drop in the proportion of children consuming vegetables. Parents perhaps have less control over what children eat as they get older.

The observed mean and median energy intakes were somewhat below the EAR in both boys and girls; however, children were not falling behind standard 
Table 6 The mean weight $\left(\mathrm{g} \mathrm{day}^{-1}\right.$ ) of each food group eaten in the whole sample (not consumers only) and the percentage of children consuming each food at 18 and 43 months, with comparable data from the NDNS where available

\begin{tabular}{|c|c|c|c|c|c|c|}
\hline \multirow[b]{2}{*}{ Food group } & \multicolumn{2}{|c|}{$\begin{array}{l}\text { Foods eaten at } \\
18 \text { months }\end{array}$} & \multicolumn{2}{|c|}{$\begin{array}{l}\text { Foods eaten at } \\
43 \text { months }\end{array}$} & \multicolumn{2}{|c|}{$\begin{array}{c}\text { Foods eaten at } \\
31 / 2 \text { to } 41 / 2 \text { years in NDNS }\end{array}$} \\
\hline & $\begin{array}{l}\text { Mean } \\
\text { weight }\end{array}$ & $\begin{array}{c}\% \\
\text { Consumers }\end{array}$ & $\begin{array}{l}\text { Mean } \\
\text { weight }\end{array}$ & $\begin{array}{c}\% \\
\text { Consumers }\end{array}$ & $\begin{array}{l}\text { Mean } \\
\text { weight }\end{array}$ & $\begin{array}{c}\% \\
\text { Consumers }\end{array}$ \\
\hline $\begin{array}{l}\text { Rice and pasta } \\
\text { White bread } \\
\text { Brown and other bread } \\
\text { Wholemeal bread } \\
\text { High-fibre white bread } \\
\text { All bread }\end{array}$ & $\begin{array}{r}28.0 \\
20.4 \\
3.7 \\
7.9 \\
0.9 \\
33.0\end{array}$ & $\begin{array}{r}65.4 \\
73.7 \\
17.0 \\
34.3 \\
4.6\end{array}$ & $\begin{array}{r}35.8 \\
35.7 \\
3.5 \\
10.6 \\
1.3 \\
51.2\end{array}$ & $\begin{array}{r}68.7 \\
83.6 \\
12.5 \\
32.0 \\
5.8\end{array}$ & $\begin{array}{r}25.1 \\
34.3 \\
4.3 \\
7.1 \\
1.9 \\
47.6\end{array}$ & $\begin{array}{r}49 \\
88 \\
26 \\
26 \\
7\end{array}$ \\
\hline $\begin{array}{l}\text { High-fibre breakfast cereal } \\
\text { Other breakfast cereal } \\
\text { Biscuits } \\
\text { Cakes, buns, fruit pies } \\
\text { Puddings, ice cream }\end{array}$ & $\begin{array}{r}13.6 \\
4.5 \\
12.2 \\
8.0 \\
24.9\end{array}$ & $\begin{array}{l}72.7 \\
45.8 \\
87.2 \\
46.6 \\
57.9\end{array}$ & $\begin{array}{r}13.2 \\
9.8 \\
17.2 \\
16.0 \\
35.8\end{array}$ & $\begin{array}{l}59.0 \\
65.7 \\
87.7 \\
55.4 \\
69.2\end{array}$ & $\begin{array}{l}10.0 \\
10.6 \\
16.7 \\
12.8 \\
29.7\end{array}$ & $\begin{array}{l}58 \\
72 \\
88 \\
61 \\
-\end{array}$ \\
\hline $\begin{array}{l}\text { Whole milk } \\
\text { Semi-skimmed milk } \\
\text { Skimmed milk } \\
\text { All milk } \\
\text { Cheese } \\
\text { Yoghurt, fromage frais } \\
\text { Eggs }\end{array}$ & $\begin{array}{r}391.0 \\
30.5 \\
1.6 \\
465.2 \\
6.9 \\
40.9 \\
6.4\end{array}$ & $\begin{array}{r}90.2 \\
14.6 \\
1.4 \\
\\
57.2 \\
69.8 \\
28.8\end{array}$ & $\begin{array}{r}260.4 \\
77.7 \\
1.5 \\
343.1 \\
9.1 \\
39.3 \\
7.4\end{array}$ & $\begin{array}{r}83.7 \\
33.3 \\
2.2 \\
98.7 \\
58.2 \\
63.9 \\
29.7\end{array}$ & $\begin{array}{r}176.3 \\
59.9 \\
6.7 \\
247.2 \\
6.3 \\
23.5 \\
9.1\end{array}$ & $\begin{array}{r}80 \\
38 \\
7 \\
\\
57 \\
- \\
47\end{array}$ \\
\hline $\begin{array}{l}\text { Butter } \\
\text { Polyunsaturated spreads/oils } \\
\text { Low-fat spreads } \\
\text { Other fat spreads/oils } \\
\text { All fat spreads/oils }\end{array}$ & $\begin{array}{l}1.4 \\
2.2 \\
1.2 \\
1.2 \\
6.0\end{array}$ & $\begin{array}{l}26.4 \\
39.4 \\
21.2 \\
21.2\end{array}$ & $\begin{array}{l}2.4 \\
3.9 \\
1.6 \\
1.4 \\
9.4\end{array}$ & $\begin{array}{l}27.7 \\
47.4 \\
20.8 \\
20.0\end{array}$ & $\begin{array}{l}1.3 \\
2.5 \\
1.4 \\
1.9 \\
7.2\end{array}$ & $\begin{array}{l}29 \\
- \\
- \\
-\end{array}$ \\
\hline $\begin{array}{l}\text { Pork } \\
\text { Beef } \\
\text { Bacon, ham } \\
\text { Lamb } \\
\text { Liver } \\
\text { Sausages } \\
\text { Burgers, kebabs } \\
\text { Pies } \\
\text { Coated chicken, turkey } \\
\text { Chicken, turkey dishes } \\
\text { Other meat products } \\
\text { All meat }\end{array}$ & $\begin{array}{r}2.4 \\
9.4 \\
2.8 \\
6.9 \\
1.5 \\
4.6 \\
0.8 \\
3.2 \\
1.6 \\
8.0 \\
0.6 \\
41.9\end{array}$ & $\begin{array}{r}15.2 \\
36.8 \\
32.7 \\
18.7 \\
7.5 \\
32.9 \\
5.5 \\
14.7 \\
10.4 \\
44.8 \\
8.4\end{array}$ & $\begin{array}{r}3.9 \\
9.3 \\
5.3 \\
6.1 \\
0.9 \\
6.6 \\
1.3 \\
3.6 \\
5.0 \\
12.7 \\
0.9 \\
55.4\end{array}$ & $\begin{array}{r}15.3 \\
24.9 \\
45.1 \\
16.2 \\
4.0 \\
35.4 \\
5.5 \\
12.6 \\
24.1 \\
44.8 \\
9.9\end{array}$ & $\begin{array}{r}1.9 \\
12.2 \\
4.4 \\
2.0 \\
0.2 \\
10.5 \\
4.3 \\
6.4 \\
4.3 \\
7.1 \\
5.1 \\
58.4\end{array}$ & $\begin{array}{r}19 \\
46 \\
46 \\
15 \\
4 \\
54 \\
26 \\
27 \\
24 \\
52 \\
30\end{array}$ \\
\hline $\begin{array}{l}\text { Oily fish } \\
\text { Coated white fish } \\
\text { Other fish } \\
\text { All fish }\end{array}$ & $\begin{array}{r}1.4 \\
5.6 \\
3.1 \\
10.1\end{array}$ & $\begin{array}{l}11.4 \\
32.5 \\
13.7\end{array}$ & $\begin{array}{r}2.5 \\
8.4 \\
3.1 \\
14.4\end{array}$ & $\begin{array}{l}13.6 \\
35.9 \\
10.6\end{array}$ & $\begin{array}{r}1.3 \\
6.9 \\
1.8 \\
10.0\end{array}$ & $\begin{array}{r}15 \\
38 \\
9\end{array}$ \\
\hline $\begin{array}{l}\text { Raw tomatoes } \\
\text { Carrots, raw } \\
\text { Other salad/raw vegetables } \\
\text { Carrots, cooked } \\
\text { Green leafy vegetables } \\
\text { Peas } \\
\text { Tomatoes, tinned/cooked } \\
\text { Other cooked vegetables } \\
\text { All vegetables } \\
\text { Baked beans } \\
\text { Potatoes, fried, roast, chips } \\
\text { Other potatoes } \\
\text { Total potatoes }\end{array}$ & $\begin{array}{r}2.0 \\
0.3 \\
1.2 \\
10.1 \\
8.9 \\
7.3 \\
1.2 \\
7.2 \\
39.2 \\
16.1 \\
17.6 \\
29.2 \\
46.8\end{array}$ & $\begin{array}{r}14.3 \\
3.6 \\
15.3 \\
64.9 \\
52.6 \\
56.7 \\
10.7 \\
51.2 \\
91.6 \\
46.1 \\
56.1 \\
78.3\end{array}$ & $\begin{array}{r}3.5 \\
1.2 \\
4.2 \\
8.8 \\
7.9 \\
6.2 \\
0.7 \\
6.6 \\
40.1 \\
15.0 \\
32.1 \\
25.0 \\
57.1\end{array}$ & $\begin{array}{r}18.2 \\
7.0 \\
26.9 \\
47.4 \\
39.7 \\
40.4 \\
3.9 \\
37.6 \\
83.0 \\
40.1 \\
72.3 \\
62.6 \\
92.7\end{array}$ & $\begin{array}{r}2.1 \\
1.7 \\
3.5 \\
4.9 \\
2.8 \\
6.8 \\
0.3 \\
9.8 \\
32.2 \\
11.3 \\
29.3 \\
26.0 \\
55.3\end{array}$ & $\begin{array}{r}17 \\
13 \\
27 \\
53 \\
33 \\
48 \\
2 \\
61 \\
- \\
45 \\
76 \\
77\end{array}$ \\
\hline $\begin{array}{l}\text { Citrus fruit } \\
\text { Apples and pears } \\
\text { Bananas } \\
\text { Other fresh fruit } \\
\text { All fruit }\end{array}$ & $\begin{array}{r}8.5 \\
13.4 \\
28.5 \\
10.8 \\
63.9\end{array}$ & $\begin{array}{l}22.1 \\
44.0 \\
61.1 \\
40.1 \\
84.1\end{array}$ & $\begin{array}{r}6.3 \\
26.8 \\
21.4 \\
11.7 \\
69.0\end{array}$ & $\begin{array}{l}19.5 \\
56.9 \\
47.3 \\
39.5 \\
82.6\end{array}$ & $\begin{array}{r}6.1 \\
16.5 \\
14.0 \\
10.1 \\
49.7\end{array}$ & $\begin{array}{l}24 \\
49 \\
40 \\
32\end{array}$ \\
\hline $\begin{array}{l}\text { Savoury snacks, crisps } \\
\text { Chocolate confectionery } \\
\text { Sugar confectionery } \\
\text { Sugar, preserves, sweet spreads } \\
\text { Fruit juice } \\
\text { Tea } \\
\text { Normal fizzy drinks and cordials } \\
\text { Diet fizzy drinks and cordials }\end{array}$ & $\begin{array}{l}6.2 \\
6.9 \\
3.8\end{array}$ & $\begin{array}{l}65.6 \\
63.3 \\
18.4 \\
55.7 \\
38.0\end{array}$ & $\begin{array}{r}11.7 \\
11.6 \\
5.2 \\
6.8 \\
64.2 \\
23.1 \\
128.5 \\
321.5\end{array}$ & $\begin{array}{l}75.2 \\
67.8 \\
41.9 \\
70.5 \\
44.0 \\
24.6 \\
59.0 \\
75.0\end{array}$ & $\begin{array}{r}10.4 \\
12.3 \\
12.4 \\
6.1 \\
58.2 \\
34.8 \\
282.5 \\
127.0\end{array}$ & $\begin{array}{l}81 \\
76 \\
67 \\
- \\
36 \\
38 \\
90 \\
52\end{array}$ \\
\hline
\end{tabular}

${ }^{*}$ Adjusted to equal contribution from boys to girls. 
growth curves ${ }^{40}$. Other recent surveys of dietary intake in pre-school children have also found intakes lower than the $\mathrm{EAR}^{11,13}$. However, observed energy intakes were closer to predicted energy intakes based on doubly labelled water measurements of energy expenditure. Furthermore, an attempt was made to estimate the level of under-recording of dietary intake in this study. The level found was highly dependent on the method used to calculate predicted energy intake, so that it was very difficult to draw any conclusions about the real level of under-recording. The method using doubly labelled water data and the one using the lower level of activity agreed fairly closely, suggesting that children are less active nowadays than in the past. Perhaps this is the reason why the EAR is much higher than the recorded intake of contemporary children. No adjustment was made for under-recording in the NDNS, which estimated even lower energy intakes.

The contribution to energy from fat was close to the recommended average for the adult population of $35 \%{ }^{14}$. However, the contribution from saturated fat was higher than the recommended $10 \%$ for adults, and that from polyunsaturated fat was lower, $6-10 \%$ is recommended. The proportion of energy derived from NME sugar was much higher than the recommended maximum of $10 \%$, whereas that derived from starch was somewhat lower than the recommendation of around 37\%. A major shift in dietary habits would be necessary to move these proportions towards the recommendations for adults. Comparison (Table 4) shows that, if anything, the diet recorded in CIF in 1996/7 was further from the recommendations than that recorded in the NDNS in $1992 / 3$ except with respect to sugar and polyunsaturated fat. It has been suggested that the diets of very young children should not be restricted in fat content in case this results in poor growth; a further analysis of these data has shown no grounds for concern in this respect ${ }^{41}$.

For most vitamins and minerals the mean and median intakes in CIF were well in excess of the $\mathrm{RNI}^{14}$, implying that the chances of any of the children in the CIF group having an inadequate intake of one of these nutrients was extremely small. The exceptions to this were iron, zinc and vitamin D. Although the mean zinc intake was above the RNI, the median intake was slightly below it. The mean and median iron intakes fell between the RNI and the EAR. It was therefore possible that some of the children may have been having inadequate intakes of these minerals. Vitamin D intake was roughly a quarter of the RNI. However, this does not necessarily imply a problem with vitamin D deficiency, as in practice most vitamin $\mathrm{D}$ is derived from the action of sunlight on the skin. In addition, the contribution of supplements, taken by less than $25 \%$ of the children, to vitamin D intake had not been taken into account. It has been suggested that there may be a problem in Britain in winter months when there is less exposure to sunlight ${ }^{42}$. Perhaps more emphasis should be put on the recommendation that vitamin D supplements should be given to children up to 5 years of age ${ }^{43}$, especially in winter ${ }^{42}$.

The estimated nutrient intakes in this study were, for the most part, higher than those in the NDNS despite the average age of the children assessed being lower. However, this may be because of the difference in methods used rather than real differences in intake. NDNS used weighed intakes of diet over a 4-day period and there is evidence that asking people to weigh the food they eat leads to under-recording of intake ${ }^{44}$. In CIF recording was done using household measures, which may be less prone to this bias. However, because weights of food were not recorded it was necessary to estimate the portion sizes eaten and although standardisation was attempted by using the DIDO coding program, it is quite possible that the weights of some foods were overestimated. In the NDNS, intakes were adjusted according to weekday and weekend recording; in CIF we found very little difference between the days of the week and so did not adjust. In CIF very few of the recorded days were when the child was unwell (2.3\%), whereas the children in NDNS were unwell on $12 \%$ of recorded days. This would have led to higher estimates of intake in CIF since intakes of almost all nutrients were lower on days when the child was unwell compared with typical days. There was no evidence in CIF of under-recording on days when someone other than the main carer had provided meals for the child.

The only nutrient intake that was found to be lower in CIF than NDNS was total sugar, particularly NME sugar. This may be due to a much greater use of low-sugar/diet fizzy drinks and cordials in this study. Any cordial or squash that was not fully described was coded as lowsugar because this was the most used type where a full description was available. There was also a lower proportion of consumers of chocolate and sugar confectionery in this study compared with the NDNS. This was particularly marked for sugar confectionery. The mothers in CIF had, on average, higher education levels than those in the NDNS ${ }^{12}$. We have shown in previous analysis of CIF data ${ }^{45}$ that mothers in the higher educational groups are more likely to respond to health messages. Avoidance of confectionery to improve child dental health has been a consistent message over many years. Despite this, the diet of these children had deteriorated between 18 and 43 months with regard to confectionery eating.

Comparing the weights of each food group eaten and the proportion of consumers between this study and the NDNS showed that, for many foods, our estimates of food weights were higher than the weighed intakes of the NDNS. The proportion of children consuming each food was not generally higher. This may be due to the fact that this study recorded intakes over 3 days whereas the NDNS recorded over 4 days, and thus there was more 
opportunity for foods less frequently eaten to be recorded in NDNS. There were, however, some important exceptions to this in the meat groups. Several months prior to starting the collection of the dietary diaries at 43 months, the first major publicity relating to bovine spongiform encephalopathy (BSE) occurred. This associated the eating of beef with disease in humans. It seems therefore that parents may have changed the way they fed their children in response to this: our study recorded lower intakes of beef burgers, sausages and pies than the NDNS, but higher intakes of chicken and turkey. This conclusion is strengthened by the recorded drop in the proportion of consumers of beef in CIF between 18 and 43 months. Further study of this group of children could reveal whether this drop in meat intake affected health; certainly it could have contributed to the relatively low iron and zinc intakes observed.

Another important area of difference between this study and the NDNS was a higher mean intake of whole milk and a lower proportion of skimmed and semiskimmed milk users. Perhaps the recommendation to use whole milk rather than reduced-fat milk as a drink for the under fives is having an impact ${ }^{43}$.

The children in this study had an average daily intake of $40 \mathrm{~g}$ of vegetables and $69 \mathrm{~g}$ of fruit compared with $32 \mathrm{~g}$ and $50 \mathrm{~g}$, respectively, in the NDNS. Increasing fruit and vegetable intake is a health message that has been widely publicised, particularly in relation to cancer risk $^{7}$, and there is some evidence here of its efficacy. Despite this there were a number of children who ate no vegetables or fruit during the recording period. It will be important to track these dietary habits further and assess their consequences.

\section{Acknowledgements}

We are extremely grateful to all the parents and children who took part in this study and to the midwives for their help in recruiting them. We would like to acknowledge the dedicated work of the ALSPAC study team, which includes interviewers, computer technicians, clerical workers, research scientists, volunteers and managers. We would particularly like to thank the staff of the Children in Focus research clinics and John Emmett for his work on the nutrient database and analysis program. The ALSPAC study could not have taken place without financial support of the MRC, the Wellcome Trust, the Department of the Environment, MAFF, various medical charities and commercial companies. This analysis was supported by the Department of Health. The ALSPAC study is part of the WHO-initiated European Longitudinal Study of Pregnancy and Childhood. The Children in Focus sub-study is, however, unique to ALSPAC.

\section{References}

1 Clarke R, Frost C, Collins R, Appleby P, Peto R. Dietary lipids and blood cholesterol: quantitative meta-analysis of metabolic ward studies. Br. Med. J. 1997; 214: 112-7.

2 Grundy SM. Comparison of monounsaturated fatty acids and carbohydrates for lowering plasma cholesterol. New Engl. J. Med. 1986; 314: 745-8.

3 Mensink RP, Katan MB. Effect of monounsaturated fatty acids versus complex carbohydrates on high-density lipoproteins in healthy men and women. Lancet 1987; I: $122-5$.

4 Ness AR, Khaw KT, Bingham S, Day NE. Vitamin C status and serum lipids. Eur. J. Clin. Nutr. 1996; 50: 724-9.

5 Walker ARP. Diet and cancer. Br. Med.J. 1994; 309: 1439.

6 Potter JD. Food, Nutrition and the Prevention of Cancer: A Global Perspective, 1st ed. Washington, DC: World Cancer Research Fund/American Institute of Cancer Research, 1997.

7 Department of Health. Nutritional Aspects of the Development of Cancer. Report of the Working Group on Diet and Cancer, Committee on Medical Aspects of Food and Nutrition Policy. Report on Health and Social Subjects No. 48. London: HMSO, 1998.

8 Uemura K, Pisa Z. Trends in cardiovascular disease mortality in industrialized countries since 1950. World Health Stat. Quart. 1988; 41: 155-78.

9 National Heart, Lung and Blood Institute. Report of the Task Force on Research in Epidemiology and Prevention of Cardiovascular Diseases. Bethesda, MD: National Institutes of Health, 1994.

10 McGill HCJ. Morphologic development of the atherosclerotic plaque. In: Lauer RM, Shekelle RR, eds. Childhood Prevention of Atherosclerosis and Hypertension. New York, NY: Raven Press, 1980; 41-9.

11 Payne JA, Belton NR. Nutrients intake and growth in preschool children. II. Intake of minerals and vitamins. J. Hum. Nutr. Diet. 1992; 5: 299-304.

12 Cowin I, Emmett P, ALSPAC Study Team. Diet in a group of 18-month-old children in South-West England, and comparison with the results of a national survey. J. Hum. Nutr. Diet 2000; 13: 87-100

13 Gregory JR, Collins DL, Davies PSW, Hughes JM, Clarke PC. The Diet and Nutrition Survey: Children aged 1 1/2 to 4 1/2 years. Vol. 1. Report of the Diet and Nutrition Survey. London: HMSO, 1995.

14 Department of Health. Dietary Reference Values for Food, Energy and Nutrients for the United Kingdom. Report on Health and Social Subjects No. 41. London: HMSO, 1991.

15 Golding J, ALSPAC Study Team. Children of the nineties: a resource for assessing the magnitude of long-term effects of prenatal, perinatal and subsequent events. Obstetrics 1996; 8: 89-92.

16 ALSPAC website. http://www.ich.bris.ac.uk/alspac.html.

17 Price GM, Paul AA, Key FB, Harter AC, Cole TJ, Day KC, Wadsworth MEJ. Measurement of diet in a large national survey: comparison of computerised and manual coding of records in household measures. J. Hum. Nutr. 1995; 8 417-28.

18 Holland B, Welch AA, Unwin ID, Buss DH, Paul AA, Southgate DAT. McCance \& Widdowson's The Composition of Foods, 5th ed. London: The Royal Society of Chemistry and MAFF, 1991.

19 Holland B, Unwin ID, Buss DH. Cereals and Cereal Products. The Third Supplement to McCance \& Widdowson's The Composition of Foods, 4th ed. London: The Royal Society of Chemistry and MAFF, 1988.

20 Holland B, Unwin ID, Buss DH. Milk Products and Eggs. The Fourth Supplement to McCance \& Widdowson's The Composition of Foods, 4 th ed. London: The Royal Society of Chemistry and MAFF, 1989. 
21 Holland B, Unwin ID, Buss DH. Vegetables, Herbs and Spices. The Fifth Supplement to McCance \& Widdowson's The Composition of Foods, 4th ed. London: The Royal Society of Chemistry and MAFF, 1991.

22 Holland B, Unwin ID, Buss DH. Fruit and Nuts. The First Supplement to McCance \& Widdowson's The Composition of Foods, 5th ed. London: The Royal Society of Chemistry and MAFF, 1992.

23 Holland $\mathrm{B}$, Welch AA, Buss DH. Vegetable Dishes. The Second Supplement to McCance \& Widdowson's The Composition of Foods, 5th ed. London: The Royal Society of Chemistry and MAFF, 1992.

24 Holland B, Brown J, Buss DH. Fish and Fish Products. The Third Supplement to McCance \& Widdowson's The Composition of Foods, 5th ed. London: The Royal Society of Chemistry and MAFF, 1993.

25 Chan W, Brown J, Buss DH. Miscellaneous Foods. Supplement to McCance \& Widdowson's The Composition of Foods. London: The Royal Society of Chemistry and MAFF, 1994.

26 Chan W, Brown J, Church SM, Buss DH. Meat Products and Dishes. London: The Royal Society of Chemistry and MAFF, 1996.

27 Chan W, Brown J, Lee SM, Buss DH. Meat, Poultry and Game. London: The Royal Society of Chemistry and MAFF, 1995.

28 Ministry of Agriculture, Fisheries and Food (MAFF). Food Portion Sizes, 2nd ed. London: HMSO, 1993.

29 Cowin IS, Emmett PM. The effect of missing data in the supplements to McCance and Widdowson's food tables on calculated nutrient intakes. Eur. J. Clin. Nutr. 1999; 53 $891-4$.

30 Price GM, Paul AA, Cole TJ, Wadsworth MEJ. Characteristics of the low energy reporters in a longitudinal national dietary survey. Br. J. Nutr. 1997; 77: 833-51.

31 Briefel RR, Sempos CT, McDowell MA, Chien S, Alaimo K. Dietary methods research in the third National Health and Nutrition Examination Survey: underreporting of energy intake. Am. J. Clin. Nutr. 1997; 4(Suppl.: 1203S-9S.

32 Champagne CM, Baker NB, DeLany JP, Harsha DW, Bray GA. Assessment of energy intake underreporting by doubly labeled water and observations on reported nutrient intakes in children. J. Am. Diet. Assoc. 1998; 4: 426-33.
33 Davies PSW, Coward WA, Gregory J, White A, Mills A. Total energy expenditure and energy intake in the pre-school child: a comparison. Br. J. Nutr. 1994; 72: 13-20.

34 Davies PSW, Gregory J, White A. Energy expenditure in children aged 1.5 to 4.5 years: a comparison with current recommendations for energy intake. Eur.J. Clin. Nutr. 1995; 49: 360-4.

35 World Health Organization (WHO). Energy and Protein Requirements. Report of a Joint FAO/WHO/UNU Meeting. Technical Report Series No. 724. Geneva: WHO, 1985.

36 Goran MI, Carpenter WH, Poehlman ET. Total energy expenditure in 4 to 6 year old children. Am.J. Physiol. 1993; 264: E706-11.

37 Keys A, Anderson JT, Grande F. Prediction of serum cholesterol responses of man to changes in fats in the diet. Lancet 1957; 2: 959-66.

38 Hegsted DM, McGandy RB, Myers ML, Stare FJ. Quantitative effects of dietary fat on serum cholesterol in man. Am.J. Clin. Nutr. 1965; 17: 281-5.

39 Grundy SM, Denke MA. Dietary influences on serum lipids and lipoproteins. J. Lipid Res. 1990; 31: 1149-72.

40 Reilly JJ, Dorosty AR, Emmett PM. Prevalence of overweight and obesity in British children: cohort study. Br. Med. J. 1999; 319: 1039.

41 Rogers I, Emmett P, ALSPAC Study Team. Fat content of the diet among pre-school children in South-west Britain. II. Relationship with growth, blood lipids and iron status. Pediatrics 108(3). URL: http://www.pediatrics.org/cgi/content/full/108/3/el;

42 Davies PSW, Bates CJ, Cole TJ, Prentice A, Clarke PC. Vitamin D: seasonal and regional differences in preschool children in Great Britain. Eur. J. Clin. Nutr. 1999; 53: 195-8.

43 Department of Health. Weaning and the Weaning Diet. Report on Health and Social Subjects No. 45. London: HMSO, 1994.

44 Bingham S, Welch A, Cassidy A, Runswick S. The use of $24 \mathrm{~h}$ urine nitrogen to detect bias in the reported habitual food intake of individuals assessed from weighted dietary records. Proc. Nutr. Soc. 1991; 50: 32A.

45 North K, Emmett PM, Noble SM, ALSPAC Study Team. Types of drinks consumed by infants at 4 and 8 months of age: socio-demographic variations. J. Hum. Nutr. Diet. 2000; 13: $71-82$. 